Article

\title{
Virucidal and Immunostimulating Activities of Monogalactosyl Diacylglyceride from Coccomyxa sp. KJ, a Green Microalga, against Murine Norovirus and Feline Calicivirus
}

\author{
Kyoko Hayashi ${ }^{1}$, Satoko Komatsu ${ }^{2}$, Hitoshi Kuno ${ }^{2}$, Satomi Asai ${ }^{3}$, Iori Matsuura ${ }^{1}$, Vyankatesh Ramlu Kudkyal ${ }^{4}$ \\ and Toshio Kawahara 1,4,* \\ 1 College of Life and Health Sciences, Chubu University, Kasugai 487-8501, Japan; \\ kyhayashi@cronos.ocn.ne.jp (K.H.); rb21012-0952@sti.chubu.ac.jp (I.M.) \\ 2 DENSO Corporation, Kariya 448-8661, Japan; satoko.komatsu.j8b@jp.denso.com (S.K.); \\ hitoshi.kuno.j7c@jp.denso.com (H.K.) \\ 3 School of Medicine, Tokai University, Isehara 259-1193, Japan; sa@is.icc.u-tokai.ac.jp \\ 4 Graduate School of Engineering, Chubu University, Kasugai 487-8501, Japan; te20801-7769@sti.chubu.ac.jp \\ * Correspondence: toshi@isc.chubu.ac.jp; Tel.: +81-568-51-9314
}

Citation: Hayashi, K.; Komatsu, S.; Kuno, H.; Asai, S.; Matsuura, I.;

Kudkyal, V.R.; Kawahara, T.

Virucidal and Immunostimulating Activities of Monogalactosyl Diacylglyceride from Coccomyxa sp

$\mathrm{KJ}$, a Green Microalga, against

Murine Norovirus and Feline

Calicivirus. Mar. Drugs 2022, 20, 131. https://doi.org/10.3390/

md20020131

Academic Editor: Hitoshi Sashiwa

Received: 5 January 2022

Accepted: 7 February 2022

Published: 10 February 2022

Publisher's Note: MDPI stays neutral with regard to jurisdictional claims in published maps and institutional affiliations.

Copyright: (C) 2022 by the authors. Licensee MDPI, Basel, Switzerland. This article is an open access article distributed under the terms and conditions of the Creative Commons Attribution (CC BY) license (https:// creativecommons.org/licenses/by/ $4.0 /)$.
Abstract: Human noroviruses are the most common pathogens causing acute gastroenteritis and may lead to more severe illnesses among immunosuppressed people, including elderly and organ transplant recipients. To date, there are no safe and effective vaccines or antiviral agents for norovirus infections. In the present study, we aimed to demonstrate the antiviral activity of monogalactosyl diacylglyceride (MGDG) isolated from a microalga, Coccomyxa sp. KJ, against murine norovirus $(\mathrm{MNV})$ and feline calicivirus (FCV), the surrogates for human norovirus. MGDG showed virucidal activities against these viruses in a dose- and time-dependent manner-MGDG at $100 \mu \mathrm{g} / \mathrm{mL}$ reduced the infectivity of MNV and FCV to approximately $10 \%$ after $60 \mathrm{~min}$ incubation. In the animal experiments of MNV infection, intraoral administration of MGDG (1 mg/day) exerted a therapeutic effect by suppressing viral shedding in the feces and produced high neutralizing antibody titers in sera and feces. When MGDG was orally administered to immunocompromised mice treated with 5-fluorouracil, the compound exhibited earlier stopping of viral shedding and higher neutralizing antibody titers of sera than those in the control mice administered with distilled water. Thus, MGDG may offer a new therapeutic and prophylactic alternative against norovirus infections.

Keywords: norovirus; monogalactosyl diacylglyceride; in vitro antiviral activity; mouse model; immunocompromised mice; neutralizing antibody

\section{Introduction}

Norovirus, belonging to the family Caliciviridae, is a non-enveloped virus with an icosahedral structure of 38-nm diameter. Its genome consists of single-stranded RNA of approximately $7.5 \mathrm{~kb}$ in length. Human noroviruses (HNoVs) are the most common viral cause of acute gastroenteritis, accounting for approximately $20 \%$ of diseases worldwide $[1,2]$. $\mathrm{HNoV}$ infection causes profuse vomiting and diarrhea, which are typically self-limiting. Although several types of candidate vaccines are being developed [3], there are no reports on approved safe and effective vaccines and anti-norovirus drugs. In the absence of vaccines and antiviral agents for $\mathrm{HNoV}$, developing prophylactic or therapeutic measures against the virus remains an important issue.

Monogalactosyl diacylglyceride (MGDG) is a glycoglycerolipid found in vegetables, fruits, and grains [4]. As MGDG is consumed daily [5], its toxicity seems unproblematic. In addition, MGDGs from algae exhibit anti-tumor and anti-inflammatory activities [6,7]. Recently, it was found that MGDG isolated from a microalga, Coccomyxa sp. KJ (IPOD FERM BP-22254) displays a virucidal effect on herpes simplex virus type 2 (HSV-2) [8]. 
HSV-2, an enveloped virus, is a genital herpes pathogen. Morphological studies have suggested that MGDG can lyse the viral envelope as well as the viral capsid inside the envelope. Based on these findings, we expect that MGDG might also show inhibitory effects on noroviruses having the capsid on the outermost surface.

Owing to insufficient replication in the cell culture system for HNoVs, we used two cultivable strains of noroviruses, feline calicivirus (FCV) and murine norovirus (MNV), as surrogates for HNoVs in the present study.

This study aimed to evaluate the potential of MGDG as a candidate for developing antiviral agents to treat $\mathrm{HNoV}$ infections. We assessed the in vitro virucidal activities of MGDG against FCV and MNV and its in vivo therapeutic effects in MNV-infected mice in both immunocompetent and immunocompromised states. In mouse models of MNV, the virus infects macrophages and dendritic cells, possibly in a manner dependent on microfold (M) cells associated with Peyer's patches [9]. In MNV-infected mice, while the innate immune responses, including interferon production, are important for suppressing viral replication, initiating the adaptive immune response plays a key role in clearing viral infection and generating immunological memory to prevent reinfection [10]. The findings of this study offer a new therapeutic and prophylactic alternative against norovirus infections.

\section{Results}

\subsection{In Vitro Antiviral Activity of MGDG}

MGDG was evaluated for its antiviral potency against MNV and FCV, added immediately after viral infection. The values of selectivity indices calculated from $\mathrm{CC}_{50} / \mathrm{EC}_{50}$ were $1.1 \pm 0.14$ and $1.1 \pm 0.035$ for MNV and FCV, respectively (Table 1). In general, when a selectivity index is $>10$, a sample can be regarded as possessing antiviral activity. These results showed that MGDG had no marked anti-MNV and anti-FCV activities in vitro.

Table 1. Anti-feline calicivirus (FCV) and anti-mouse norovirus (MNV) activities of monogalactosyl diacylglyceride.

\begin{tabular}{cccc}
\hline Virus & $\begin{array}{c}\text { Cytotoxicity } \\
\left(\mathrm{CC}_{\mathbf{5 0}}, \boldsymbol{\mu g} / \mathbf{m L}\right)\end{array}$ & $\begin{array}{c}\text { Antiviral Activity } \\
\left(\mathrm{EC}_{\mathbf{5 0}}, \boldsymbol{\mu g} / \mathbf{m L}\right)\end{array}$ & $\begin{array}{c}\text { Selectivity Index } \\
\left(\mathrm{CC}_{\mathbf{5 0}} / \mathrm{EC}_{\mathbf{5 0}}\right)\end{array}$ \\
\hline $\mathrm{FCV}$ & $122 \pm 11$ & $117 \pm 6.4$ & $1.1 \pm 0.035$ \\
$\mathrm{MNV}$ & $195 \pm 9.2$ & $177 \pm 11$ & $1.1 \pm 0.14$ \\
\hline
\end{tabular}

Each value represents the means \pm SD from independent duplicate assays. Sample was added immediately after the viral infection.

As reported previously [8], MGDG affects the HSV from outside the host cell by directly inactivating virus particles released from infected cells. Therefore, we investigated whether MGDG reduces the infectivity of MNV and FCV due to the interaction between MGDG and virus particles. The virucidal activity of MGDG was assessed using an assay based on incubating the compound-virus mixture before calculating residual virus infectivity via a plaque assay. As shown in Figure 1, MGDG inactivated both MNVs and FCVs in a dose- and time-dependent manner.

Furthermore, we assessed the effects of an organic substance, bovine serum albumin (BSA), on the virucidal activity of MGDG compared with that of $\mathrm{NaClO}$, a potent disinfectant agent against norovirus. Incubation of FCV with $100 \mu \mathrm{g} / \mathrm{mL} \mathrm{NaClO}$ in the absence of BSA, no infectious virus was detected within 1 min after incubation (Figure 2). However, the virucidal activity dropped remarkably in the presence of $2 \%$ or $5 \%$ BSA, with approximately $60 \% \mathrm{FCV}$ infectivity remaining even after $60 \mathrm{~min}$ of incubation. In contrast, no significant decrease in the virucidal activity of $100 \mu \mathrm{g} / \mathrm{mL}$ MGDG was observed in the presence of BSA. 
A

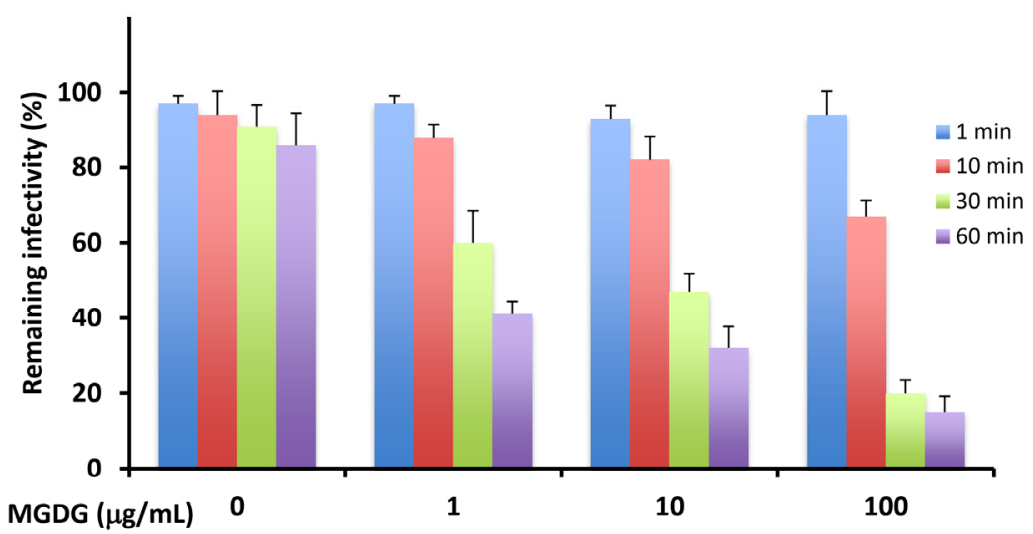

(FCV)

B

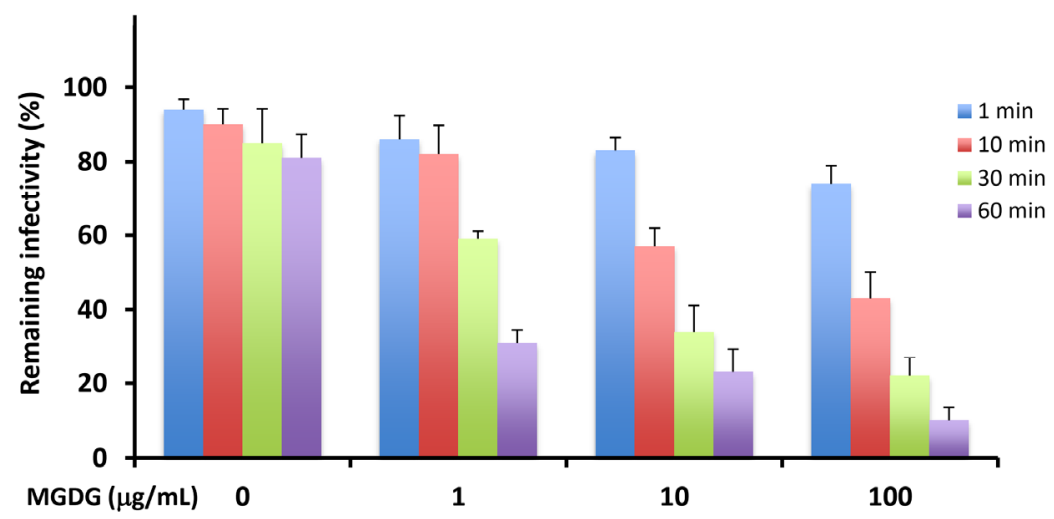

Figure 1. Virucidal activities of monogalactosyl diacylglyceride (MGDG) against murine norovirus $(\mathrm{MNV})(\mathrm{A})$ and feline calicivirus (FCV) $(\mathbf{B})$. Virus $\left(2 \times 10^{5}\right.$ plaque-forming units $\left.(\mathrm{PFU}) / \mathrm{mL}\right)$ was mixed with an equal volume of $0,1,10$, and $100 \mu \mathrm{g} / \mathrm{mL}$ MGDG and incubated for the indicated time at $37^{\circ} \mathrm{C}$. Results are expressed as the percentages of residual infectivity of MGDG-treated virus compared to the residual infectivity of the mock-treated virus control. Data are the means from independent duplicate assays.

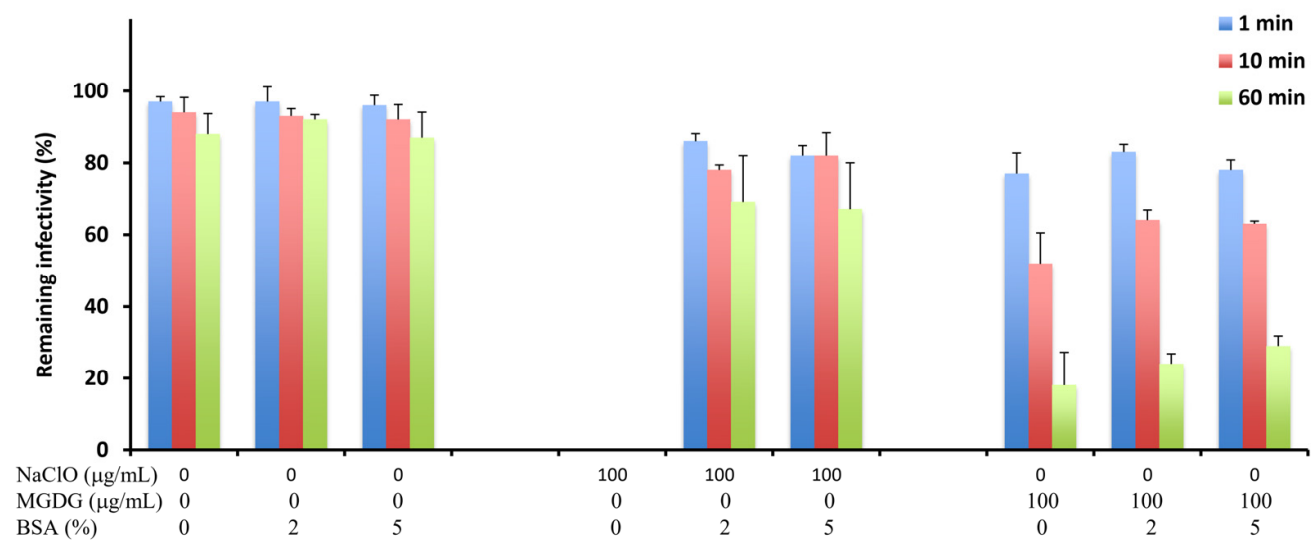

Figure 2. Virucidal activities of MGDG and sodium hypochlorite $(\mathrm{NaClO})$ against $\mathrm{FCV}$ in the presence of bovine serum albumin (BSA). FCV $\left(2 \times 10^{5} \mathrm{PFU} / \mathrm{mL}\right)$ was mixed with an equal volume of 0 and $100 \mu \mathrm{g} / \mathrm{mL}$ MGDG or $\mathrm{NaClO}$ in the presence of $0 \%, 2 \%$, and $5 \%$ BSA and incubated for the indicated time at $37^{\circ} \mathrm{C}$. Results are expressed as the percentages of residual infectivity of MGDG-treated virus compared to the residual infectivity of the mock-treated virus control. Data are the means from independent duplicate assays. 


\subsection{In Vivo Therapeutic Effects of MGDG on $M N V$ Infection}

$\mathrm{BALB} / \mathrm{c}$ mice were infected perorally with $1 \times 10^{6}$ plaque-forming units (PFU) of $\mathrm{MNV}$, and MGDG was administered $1 \mathrm{~h}$ after infection until $21 \mathrm{~d}$ post-infection (p.i.). All mice survived the experiment, and no diarrhea or weight loss was observed during the $21 \mathrm{~d}$ experimental period. The viral titers in the feces were determined by plaque assay using RAW 267.4 cells. MNV was detected in the feces of both control and MGDGadministered groups as early as $8 \mathrm{~h}$ p.i. However, MGDG-administered mice showed significantly reduced titers of $\mathrm{MNV}$ from $8 \mathrm{~h}$ to $16 \mathrm{~d}$ p.i., compared to those in the control group (Figure 3A). Viral shedding was stopped at 18 and $14 \mathrm{~d}$ p.i. in the control and MGDG-administered groups, respectively.

A
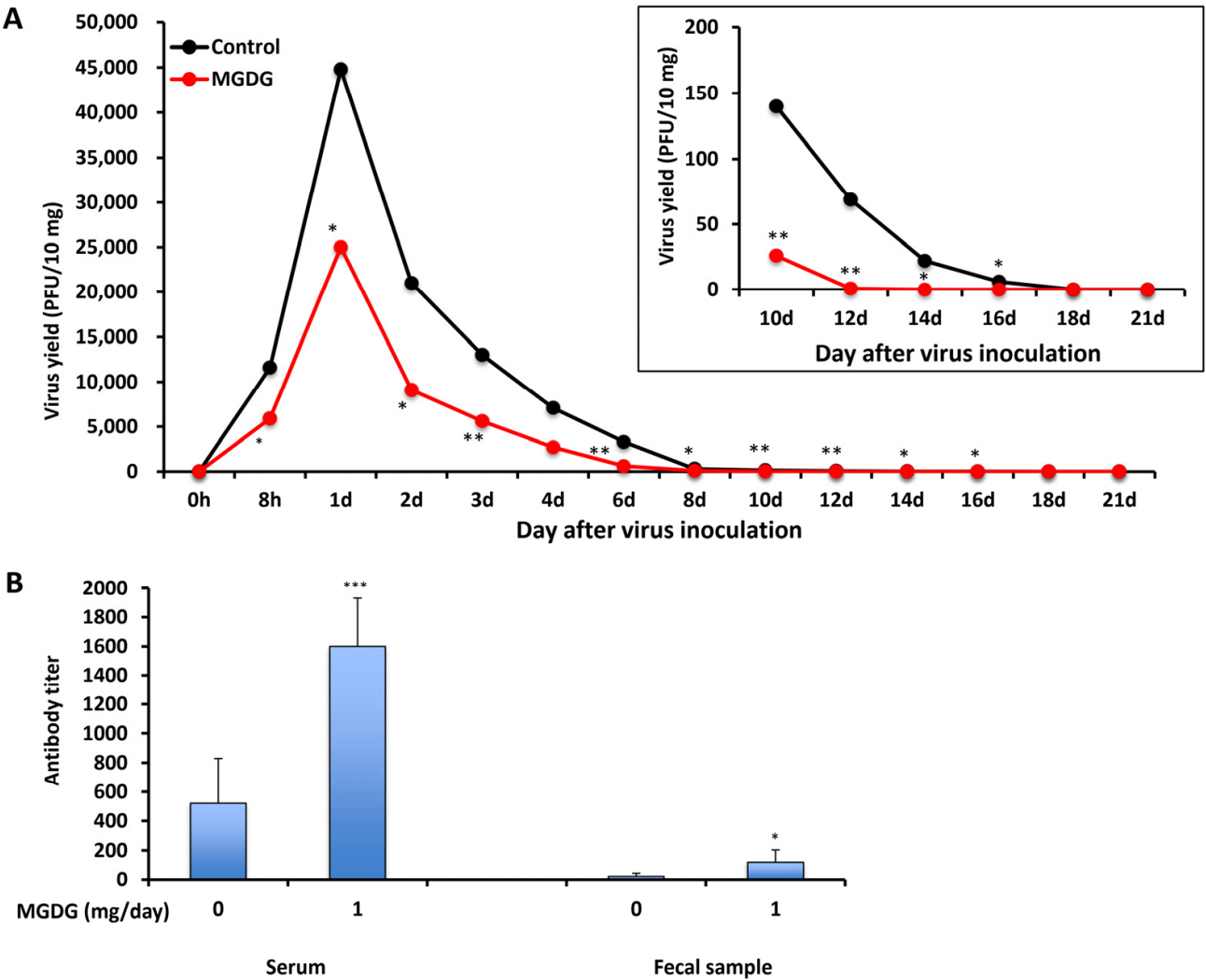

Figure 3. In vivo efficacy of MGDG. BALB/c mice ( $n=3$ per group) were inoculated with $1 \times 10^{6} \mathrm{PFU}$ of MNV, and $1 \mathrm{mg}$ of MGDG/day was administered $1 \mathrm{~h}$ after infection until $21 \mathrm{~d}$ post-infection (p.i.). The control group was administered with distilled water. (A) Virus yields in the feces collected from $0 \mathrm{~h}$ to $21 \mathrm{~d}$ p.i.; (B) neutralizing antibody titers in sera and feces at $21 \mathrm{~d}$ p.i. ${ }^{*} p<0.05$; ${ }^{* *} p<0.01$; $* * * p<0.001$ vs. control.

In an attempt to elucidate whether orally administering MGDG could stimulate systemic and local immunoresponses in MNV-infected animals, virus-neutralizing antibody titers in sera and feces were determined on day 21 p.i. (Figure 3B). The titer in serum was $1600 \pm 330$ in the MGDG-administered group, which was significantly higher than that in the control group $(520 \pm 310)(p<0.001)$. In addition, MGDG produced higher antibody titers in feces $(120 \pm 84)$ than control $(23 \pm 21)(p<0.05)$.

\subsection{In Vivo Effects of MGDG on MNV Infection in Immunocompromised Mice}

As shown in Figure 3, MGDG increased MNV-specific antibody production in immunocompetent mice. To evaluate this immunostimulatory effect in immunocompromised mice, the animals were treated with 5-fluorouracil (5-FU) to suppress the immune function. All immunocompetent mice without 5-FU treatment and immunocompromised mice with 5-FU treatment survived throughout the experiments of $21 \mathrm{~d}$. The 5-FU-treated control 
mice showed prolonged viral shedding of $>21$ days p.i. (Figure $4 B$ ) compared with immunocompetent control mice (Figure $4 \mathrm{~A}$ ) in which viral shedding ceased at $18 \mathrm{~d}$ p.i. In MGDG-administered immunocompromised mice, prolonged viral shedding at $14 \mathrm{~d}$ p.i. (Figure 4B) was observed compared with MGDG-administered immunocompetent mice (Figure 4A) in which viral shedding ceased at $12 \mathrm{~d}$ p.i. MGDG administration significantly reduced and earlier stopping of viral shedding (Figure 4B) compared with immunocompromised control mice. The neutralizing antibody titers of sera were reduced by 5-FU treatment in the control and MGDG-administered mice by $59 \%$ and $68 \%$, respectively (Figure $4 \mathrm{C}$ ). The antibody production significantly increased in the MGDG group of both immunocompetent $(p<0.001)$ and immunocompromised mice $(p<0.01)$ compared with the corresponding control groups.
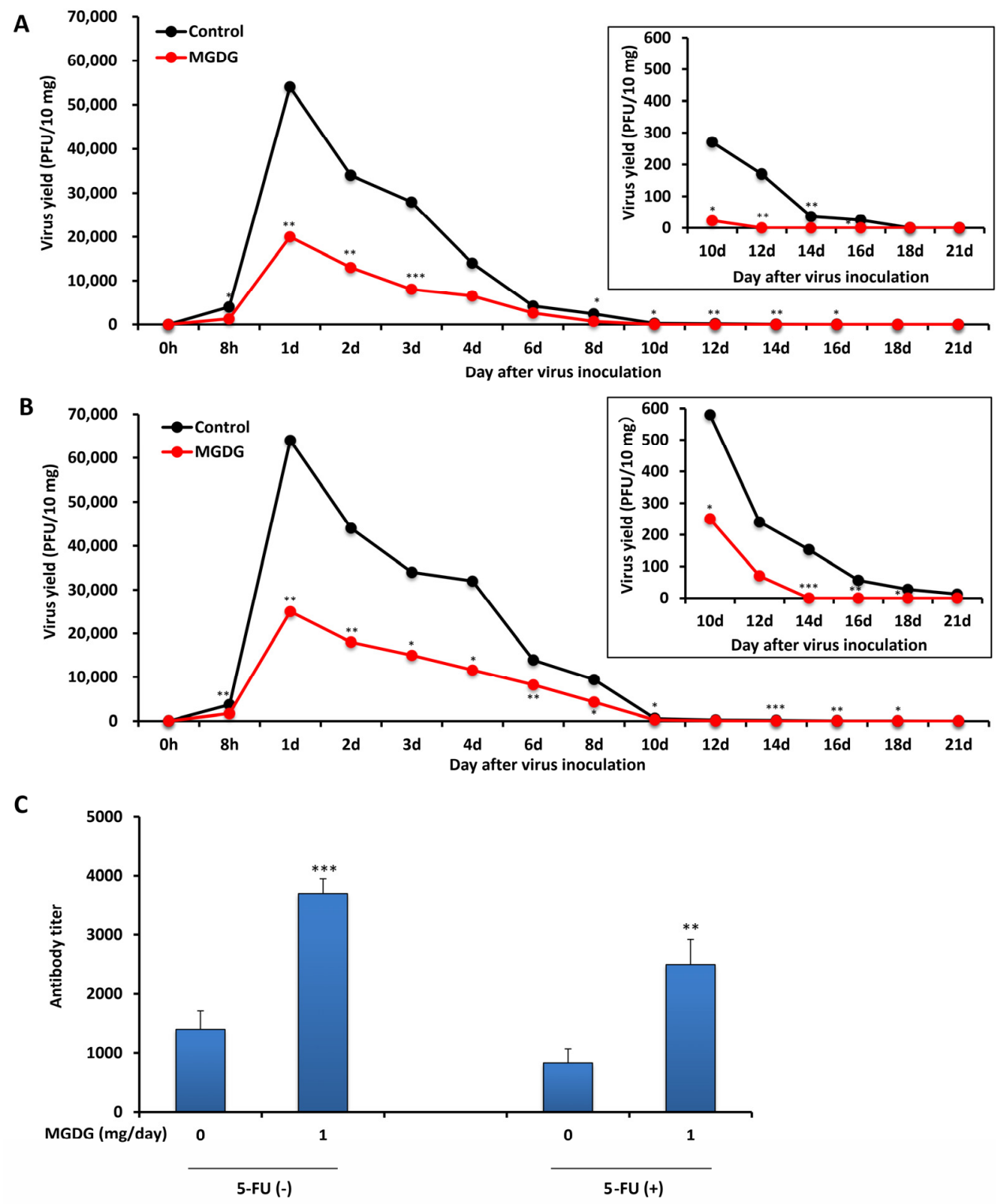

Figure 4. In vivo efficacy of MGDG in immunocompromised mice. BALB/c ( $n=5$ per group) inoculated perorally with $1 \times 10^{6} \mathrm{PFU}$ of MNV. A dose of $1 \mathrm{mg}$ MGDG/day was administered from $7 \mathrm{~d}$ before viral infection until $21 \mathrm{~d}$ p.i. The control group was administered with distilled water. Fecal 
samples were collected from $0 \mathrm{~h}$ to $21 \mathrm{~d}$ p.i. (A) Virus yields of mice without 5-fluorouracil (5-FU) treatment in the feces; (B) virus yields of mice with 5-FU treatment in the feces; $(\mathbf{C})$ neutralizing antibody titers in sera at $21 \mathrm{~d}$ p.i. in the group without 5-FU treatment [5-FU(-)] and the group with 5-FU treatment $[5-\mathrm{FU}(+)] .{ }^{*} p<0.05 ;{ }^{* *} p<0.01 ;{ }^{* * *} p<0.001$ vs. control.

\section{Discussion}

Eom et al. reported that the extract of brown alga Eisenia bicyclis and its components (dieckol and phlorofucofuroeckol-A) exhibited in vitro anti-MNV with high selectivity indices [11]. The study of in vitro inhibitory effects of fucoidans (sulfated polysaccharides) obtained from brown algae Laminaria japonica and Undaria pinnatifida against MNV and FCV have demonstrated that fucoidans exerted no marked virucidal activity after $3 \mathrm{~h}$ of incubation with the viruses at a concentration of $100 \mu \mathrm{g} / \mathrm{mL}$, and the $\log _{10}$ reduction in virus titers ranged from 0.23 to 0.52 [12]. In contrast, MGDG showed approximately $1.0 \log _{10}$ reduction in FCV titer after $1 \mathrm{~h}$ of incubation at the same concentration (Figure 1B). Orally administered fucoidans also reduced the viral titers in the feces of mice. In addition, some natural compounds derived from plants exert anti-norovirus activities. Phenolic compounds such as quercetin show virucidal against MNV [13]. Allspice oil, lemongrass oil, and citral also produced marked in vitro inactivation of MNV [14]. The extract and some components obtained from Lindera obtusiloba leaf exerted mild virucidal activity against MNV [15]. In this study, MGDG, a natural product obtained from an alga, exhibited in vitro virucidal activity against $M N V$ and $F C V$, in vivo suppressive effects on viral replication, and immunostimulating effects in MNV-infected animals.

In this study, MGDG demonstrated virucidal activity against non-enveloped viruses, FCV and MNV. Transmission electron microscopy images of MGDG-treated HSV-2 particles showed that MGDG treatment might cause morphological changes in not only the envelope but also the capsids of the virus particles, as judged from the reduction of their diameter. The MNV capsid plays a crucial role in binding to its receptor on host cells [16].

$\mathrm{NaClO}$ is effective against enveloped viruses and is recommended for disinfecting HNoV in Japan [17]; however, the presence of organic substances, such as BSA, quickly deactivates $\mathrm{NaClO}$ [17]. In this study, we showed that the virucidal activity of MGDG was maintained at a higher level even in the presence of BSA compared with the activity of $\mathrm{NaClO}$ (Figure 2).

In the in vivo study using the experimental animals, orally administered MGDG suppressed MNV excretion into the feces (Figure $3 \mathrm{~A}$ ) and elevated neutralizing antibody titers in the sera (Figure 3B). Considering that a certain level of virucidal effect of MGDG could be maintained even in the presence of organic substances (Figure 2), orally administered MGDG possibly exerted a certain degree of direct inactivation of inoculated or propagated MNV in the intestinal tract where organic substances coexist. The combination of these effects might have suppressed the viral replication and early clearance of the virus in MGDG-administered mice. Therefore, the effects of MGDG on immune function need further investigation.

As B-cell deficient mice incapable of producing norovirus-specific antibodies did not clear MNV, B cells are hypothesized to help clear the viral infection through antibody production [18]. Supporting this hypothesis, MGDG-treated mice showed high secretory antibody titers in the mucosa and early clearance of viral infection in the present study (Figure 3). Secretory IgA antibody in feces plays a crucial role in suppressing MNV replication in the intestinal mucosa. As Ward et al. [19] indicated, MNV inoculation was not associated with illness or death in experimental mice used in the present study.

Infectious gastroenteritis caused by $\mathrm{HNoV}$ is a common acute illness that is characteristically self-limiting. However, it may lead to more severe or protracted illness among young children, the elderly, and organ transplant recipients [20-23]. Immunosuppressed patients experience prolonged fecal $\mathrm{HNoV}$ shedding, shedding the viruses for months or even years after clearance of symptoms [24-26]. The immunocompromised state, which mimics the lowering of the immune function due to aging, stress, or medical intervention, 
can be experimentally produced in animals by treatment with some anti-cancer drugs, including 5-FU [27-29]. As reported previously, mice treated with 5-FU reduced the natural killer cell activity [30]. In the present study, we performed virological evaluation in MNV-inoculated mice injected with 5-FU. The shedding period of norovirus extended in an immunosuppressive state caused by 5-FU treatment in mice as well as in humans, as shown in Figure 4B. Oral administration of MGDG shortened the viral shedding period compared with the control mice, possibly due to the elevation of virus-specific antibody titers (Figure 4).

In conclusion, this study is the first to report the suppression of viral replication and immunostimulation in MNV-infected animals by the galactolipid contained in an alga. Given that the MNV capsid plays a crucial role in binding to its receptor on host cells, this study suggests that MGDG treatment might affect the viral capsids and exert its virucidal activity by inhibiting the binding of the virus to host cells via the capsids. However, the exact mechanism of virucidal action exerted by MGDG needs to be confirmed in future studies.

\section{Materials and Methods}

\subsection{Preparation of $M G D G$}

MGDG was isolated from the ethanol extract of Coccomyxa sp. KJ, grown in an inorganic medium as described previously [31], following the bioassay-guided fractionation via column chromatography as described previously [8]. Hexane solution of MGDG was subjected to gas chromatography-mass spectrometry to determine its chemical structure [8].

\subsection{Cells and Viruses}

The FCV F4 strain used in the present study was isolated from a cat with signs of respiratory tract infection [32] and obtained from Dr. Tohya, Nihon University in Japan. Crandell Rees feline kidney (CRFK) cells obtained from Nihon University were used as host cells and cultured in Eagle's minimal essential medium (MEM) supplemented with $5 \%$ fetal bovine serum (FBS) and antibiotics $(100 \mathrm{U} / \mathrm{mL}$ of penicillin and $100 \mu \mathrm{g} / \mathrm{mL}$ of streptomycin; Nacalai Tesque, Inc., Kyoto, Japan). The viruses were plaque-titrated in CRFK cells with MEM containing $1 \%$ SeaPlaque agarose (Lonza, Rockland, ME, USA). The MNV S7-PP3 strain, genetically close to MNV3 [33], was isolated from mouse stools in Japan [34]. In this study, it was obtained from Dr. Tohya, Nihon University, Japan. This strain has been widely used in investigating the receptor for MNV [35] and tests for virucidal and antiviral substances $[16,36]$. The MNV S7-PP3 strain was propagated in RAW 264.7 cells (ATCC TIB-71). The cells were cultured in Dulbecco's modified Eagle medium (DMEM) supplemented with $10 \%$ FBS and antibiotics. MNV was titrated by plaque assay in RAW 264.7 cells with DMEM containing 1.5\% SeaPlaque agarose.

\subsection{In Vitro Antiviral Assays}

MGDG was dissolved in $<0.5 \%$ dimethyl sulfoxide, which did not interfere with the growth of cells or viruses (data not shown). Control without MGDG contained $0.5 \%$ dimethyl sulfoxide. For cytotoxicity assays, CRFK and RAW 264.7 cells were seeded at a density of $1 \times 10^{4}$ cells/well in 96-well plates. After $24 \mathrm{~h}$ incubation at $37^{\circ} \mathrm{C}$, the cells were treated with $0-1000 \mu \mathrm{g} / \mathrm{mL}$ MGDG at $37^{\circ} \mathrm{C}$ for $72 \mathrm{~h}$. Viable cells were counted using the trypan blue exclusion test, and the $50 \%$ cytotoxic concentration $\left(\mathrm{CC}_{50}\right)$ was calculated from concentration-response curves. For antiviral assays, CRFK and RAW 264.7 cell monolayers in 48-well plates were infected with FCV and MNV, respectively, at $0.1 \mathrm{PFU} /$ cell for $1 \mathrm{~h}$ at room temperature. The cell monolayers were washed with phosphate-buffered saline (PBS) and further incubated at $37^{\circ} \mathrm{C}$ for $24 \mathrm{~h}$ in the presence of $0-1000 \mu \mathrm{g} / \mathrm{mL}$ MGDG. After fixation with a $10 \%$ formaldehyde solution for $2 \mathrm{~h}$ at room temperature, the cell monolayers were stained with trypan blue solution and subjected to plaque counting under the microscope [37]. Virus yields were determined using plaque assays, and the $50 \%$ effective concentration $\left(\mathrm{EC}_{50}\right)$ was obtained from the concentration-response curves. The 
antiviral activities of MGDG against FCV and MNV were estimated using the selective index calculated from the $\mathrm{CC}_{50} \mathrm{~s}$ and $\mathrm{EC}_{50} \mathrm{~s}$. Data are shown as the mean $\pm \mathrm{SD}$ from independent duplicate assays.

\subsection{Virucidal Assay}

We determined the direct inactivation of MNV and FCV by MGDG. The viruses $\left(1 \times 10^{5} \mathrm{PFU} / \mathrm{mL}\right)$ were incubated at $37{ }^{\circ} \mathrm{C}$ in the presence of $0,1,10$, and $100 \mu \mathrm{g} / \mathrm{mL}$ MGDG. After $0,1,10,30$, and $60 \mathrm{~min}, 100 \mu \mathrm{L}$ of 100 -fold dilution of the mixture was added to host cell monolayers in 35-mm dishes for $1 \mathrm{~h}$ at room temperature. Then the medium for plaque titration mentioned above was added to the dishes. The plaque number at $0 \mathrm{~h}$ was considered $100 \%$. The virucidal effects of MGDG on FCV were examined in the presence of an organic substance, BSA (Nacalai Tesque), and compared with those of $\mathrm{NaClO}$, which is frequently used as a disinfectant.

\subsection{Animals}

Female BALB/c mice (5-6 weeks old) were purchased from Japan SLC (Shizuoka, Japan). All animal experiments were performed per the animal experimentation guidelines of Chubu University and approved by the Animal Care Committee at Chubu University. After blood collection, the mice were euthanized by anesthesia. No side effects, such as diarrhea, due to virus inoculation or drug administration were observed throughout the experiments.

\subsection{Animal Experiments}

To evaluate the therapeutic effect of MGDG, mice were perorally inoculated with MNV $\left(1 \times 10^{6} \mathrm{PFU} / 0.2 \mathrm{~mL}\right.$ PBS) $(n=3$ per group). MGDG was first dissolved in $100 \%$ ethanol at $20 \mathrm{mg} / \mathrm{mL}$ and then diluted with distilled water to $1 \mathrm{mg} / 0.4 \mathrm{~mL}$, which contained $5 \%$ ethanol. MGDG treatment was initiated $1 \mathrm{~h}$ after infection with a dose of $1 \mathrm{mg} / 0.4 \mathrm{~mL} /$ day until $21 \mathrm{~d}$ p.i. by oral gavage. Control mice were administered with distilled water containing 5\% ethanol. Stools were collected from each mouse during the experimental period. For fecal MNV titers, stool sample homogenates were centrifuged at $3000 \mathrm{rpm}$ for $15 \mathrm{~min}$, and the supernatant was collected as a fecal suspension. RAW 264.7 cell monolayers in a 24-well plate were infected at room temperature for $1 \mathrm{~h}$ with $100 \mu \mathrm{L}$ of serial 10-fold dilutions of the fecal suspension for plaque titration. In another experiment, an immunocompromised group of mice was subcutaneously injected with $0.5 \mathrm{mg}$ of 5 -FU per treatment every alternate day from $7 \mathrm{~d}$ before virus inoculation $\left(1 \times 10^{6} \mathrm{PFU} / 0.2 \mathrm{~mL}\right.$ PBS) until $21 \mathrm{~d}$ after inoculation. Both immunocompromised mice with 5-FU treatment $(n=5)$ and immunocompetent mice without 5 -FU treatment $(n=5)$ were administered with $1 \mathrm{mg}$ MGDG/day from $7 \mathrm{~d}$ before virus inoculation until $21 \mathrm{~d}$ after inoculation.

\subsection{Assay for Neutralizing Antibody}

Neutralizing anti-MNV antibody titers of the serum and feces were determined using a $50 \%$ plaque reduction assay. Approximately $2 \times 10^{3} \mathrm{PFU} / \mathrm{mL}$ virus was mixed with an equal volume of serum or feces at 10 to 50,000 dilutions with PBS and incubated at $37^{\circ} \mathrm{C}$ for $1 \mathrm{~h}$. Each mixture was added at $100 \mu \mathrm{L} /$ dish onto RAW 264.7 cell monolayers in $35-\mathrm{mm}$ dishes for plaque assay. The neutralizing antibody titer was considered the highest dilution of the serum or feces, which reduced the plaque numbers by $50 \%$, compared with the control containing PBS instead of serum or feces.

\subsection{Statistical Analysis}

Comparisons between two groups of animals were made using the Student's $t$-test. The results with a $p$-value $<0.05$ were considered statistically significant. 
Author Contributions: Conceptualization, K.H. and H.K.; methodology, K.H., S.K., H.K., I.M. and V.R.K.; validation, K.H., H.K., S.A. and T.K.; resources, S.K. and H.K.; writing-original draft preparation, K.H.; writing—review and editing, S.A. and T.K.; supervision, T.K.; project administration, T.K.; funding acquisition, T.K. All authors have read and agreed to the published version of the manuscript.

Funding: This research was funded by JST Adaptable and Seamless Technology Transfer Program through Target-driven R \& D (A-STEP) Grant Number JPMJTR204H. Parts of this work were supported by JST-Mirai Grant Number JPMJMI19D4 and Cooperative Research Program of "Network Joint Research Center for Materials and Devices".

Institutional Review Board Statement: The study was conducted in accordance with the guidelines of the Declaration of Helsinki and approved by the Institutional Review Board of CHUBU UNIVERSITY (protocol code 3010060 and date of approval, 1 April 2020).

Acknowledgments: We thank Yukinobu Tohya (Nihon University Department of Veterinary Medicine, Tokyo, Japan) for providing the FCV F4 strain, MNV S7-PP3 strain, and CRFK cell line.

Conflicts of Interest: The authors declare no competing interest.

\section{References}

1. Ahmed, S.M.; Hall, A.J.; Robinson, A.E.; Verhoef, L.; Premkumar, P.; Parashar, U.D.; Koopmans, M.; Lopman, B.A. Global Prevalence of Norovirus in Cases of Gastroenteritis: A Systematic Review and Meta-analysis. Lancet Infect. Dis. 2014, 14, 725-730. [CrossRef]

2. Payne, D.C.; Vinjé, J.; Szilagyi, P.G.; Edwards, K.M.; Staat, M.A.; Weinberg, G.A.; Hall, C.B.; Chappell, J.; Bernstein, D.I.; Curns, A.T.; et al. Norovirus and Medically Attended Gastroenteritis in US Children. N. Engl. J. Med. 2013, 368, 1121-1130. [CrossRef] [PubMed]

3. Treanor, J.J.; Atmar, R.L.; Frey, S.E.; Gormley, R.; Chen, W.H.; Ferreira, J.; Goodwin, R.; Borkowski, A.; Clemens, R.; Mendelman, P.M.; et al. A Novel Intramuscular Bivalent Norovirus Virus-Like Particle Vaccine Candidate-Reactogenicity, Safety, and Immunogenicity in a phase 1 Trial in Healthy Adults. J. Infect. Dis. 2014, 210, 1763-1771. [CrossRef] [PubMed]

4. Kasai, Y.; Oshima, K.; Ikeda, F.; Abe, J.; Yoshimitsu, Y.; Harayama, S. Construction of a Self-Cloning System in the Unicellular Green Alga Pseudochoricystis ellipsoidea. Biotechnol. Biofuels 2015, 8, 94. [CrossRef]

5. Maeda, N.; Koka, Y.; Hada, T.; Yoshida, H.; Muzushina, Y. Oral Administration of Monogalactosyl Diacylglycerol from Spinach Inhibits Colon Tumor Growth in Mice. Exp. Ther. Med. 2013, 5, 17-22. [CrossRef]

6. Morimoto, T.; Nagatsu, A.; Murakami, N.; Sakakibara, J.; Tokuda, H.; Nishino, H.; Iwashima, A. Anti-Tumour-Promoting Glyceroglycolipids from the Green Alga, Chlorella vulgaris. Phytochemistry 1995, 40, 1433-1437. [CrossRef]

7. Kikuchi, H.; Tsukitani, Y.; Manda, T.; Fujii, T.; Nakanishi, H.; Kobayashi, M.; Kitagawa, I. Marine Natural Products. X. Pharmacologically Active Glycolipids from the Okinawan Marine Sponge Phyllospongia foliascens (Pallas). Chem. Pharm. Bull. 1982, 30, 3544-3547. [CrossRef]

8. Hayashi, K.; Lee, J.B.; Atsumi, K.; Kanazashi, M.; Shibayama, T.; Okamoto, K.; Kawahara, T.; Hayashi, T. In Vitro and In Vivo Anti-Herpes Simplex Virus Activity of Monogalactosyl Diacylglyceride from Coccomyxa sp. KJ (IPod FERM BP-22254), a Green Microalga. PLoS ONE 2019, 14, e0219305. [CrossRef]

9. Wobus, C.E.; Karst, S.M.; Thackray, L.B.; Chang, K.O.; Sosnovtsev, S.V.; Belliot, G.; Krug, A.; Mackenzie, J.M.; Green, K.Y.; Virgin, H.W. Replication of Norovirus in Cell Culture Reveals a Tropism for Dendritic Cells and Macrophages. PLoS Biol. 2004, 2 , e432. [CrossRef]

10. Newman, K.L.; Leon, J.S. Norovirus Immunology: Of Mice and Mechanisms. Eur. J. Immunol. 2015, 45, 2742-2757. [CrossRef]

11. Eom, S.H.; Moon, S.Y.; Lee, D.S.; Kim, H.J.; Park, K.; Lee, E.W.; Kim, T.H.; Chung, Y.H.; Lee, M.S.; Kim, Y.M. In Vitro Antiviral Activity of Dieckol and Phlorofucofuroeckol-A Isolated from Edible Brown Alga Eisenia bicyclis against Murine Norovirus. Algae 2015, 30, 241-246. [CrossRef]

12. Kim, H.; Lim, C.Y.; Lee, D.B.; Seok, J.H.; Kim, K.H.; Chung, M.S. Inhibitory Effects of Laminaria Japonica Fucoidans against Noroviruses. Viruses 2020, 12, 997. [CrossRef] [PubMed]

13. Iloghalu, U.; Holmes, B.; Khatiwada, J.; Williams, L.L. Selected Plant Extracts Show Antiviral Effects against Murine Norovirus Surrogate. Adv. Microbiol. 2019, 9, 372-384. [CrossRef]

14. Gilling, D.H.; Kitajima, M.; Torrey, J.R.; Bright, K.R. Mechanisms of Antiviral Action of Plant Antimicrobials against Murine Norovirus. Appl. Environ. Microbiol. 2014, 80, 4898-4910. [CrossRef] [PubMed]

15. Solis-Sanchez, D.; Rivera-Piza, A.; Lee, S.; Kim, J.; Kim, B.; Choi, J.B.; Kim, Y.W.; Ko, G.P.; Song, M.J.; Lee, S.J. Antiviral Effects of Lindera obtusiloba Leaf Extract on Murine norovirus-1 (MNV-1), a Human Norovirus Surrogate, and Potential Application to Model Foods. Antibiotics 2020, 9, 697. [CrossRef] [PubMed]

16. Walker, F.C.; Hassan, E.; Peterson, S.T.; Rodgers, R.; Schriefer, L.A.; Thompson, C.E.; Li, Y.; Kalugotla, G.; Blum-Johnston, C.; Lawrence, D.; et al. Norovirus Evolution in Immunodeficient Mice Reveals Potentiated Pathogenicity via a Single Nucleotide Change in the Viral Capsid. PLoS. Pathog. 2021, 17, e1009402. [CrossRef] 
17. Aoyama, T.; Kudo, T. Comparison of the Disinfecting Effect of Sodium Hypochlorite Aqueous Solution and Surfactant on Hospital Kitchen Hygiene Using Adenosine Triphosphate Swab Testing. PLoS ONE 2021, 16, e0249796. [CrossRef]

18. Chachu, K.A.; Strong, D.W.; LoBue, A.D.; Wobus, C.E.; Baric, R.S.; Virgin, H.W. Antibody Is Critical for the Clearance of Murine Norovirus Infection. J. Virol. 2008, 82, 6610-6617. [CrossRef]

19. Ward, J.M.; Wobus, C.E.; Thackray, L.B.; Erexson, C.R.; Faucette, L.J.; Belliot, G.; Barron, E.L.; Sosnovtsev, S.V.; Green, K.Y. Pathology of Immunodeficient Mice with Naturally Occurring Murine Norovirus Infection. Toxicol. Pathol. 2006, 34, 708-715. [CrossRef]

20. Trivedi, T.K.; DeSalvo, T.; Lee, L.; Palumbo, A.; Moll, M.; Curns, A.; Hall, A.J.; Patel, M.; Parashar, U.D.; Lopman, B.A Hospitalization and Mortality Associated with Norovirus Outbreaks in Nursing Homes. J. Am. Med. Assoc. 2012, 308, 1668-1675. [CrossRef]

21. Schwartz, S.; Vergoulidou, M.; Schreier, E.; Loddenkemper, C.; Reinwald, M.; Schmidt-Hieber, M.; Flegel, W.A.; Thiel, E.; Schneider, T. Norovirus Gastroenteritis Causes Severe and Lethal Complications after Chemotherapy and Hematopoietic Stem Cell Transplantation. Blood 2011, 117, 5850-5856. [CrossRef] [PubMed]

22. Bagci, S.; Eis-Hübinger, A.M.; Yassin, A.F.; Simon, A.; Bartmann, P.; Franz, A.R.; Mueller, A. Clinical Characteristics of Viral Intestinal Infection in Preterm and Term Neonates. Eur. J. Clin. Microbiol. Infect. Dis. 2010, 29, 1079-1084. [CrossRef] [PubMed]

23. Bok, K.; Green, K.Y. Norovirus Gastroenteritis in Immunocompromised Patients. N. Engl. J. Med. 2012, 367, 2126-2132. [CrossRef] [PubMed]

24. Henke-Gendo, C.; Harste, G.; Juergens-Saathoff, B.; Mattner, F.; Deppe, H.; Heim, A. New Real-Time PCR Detects Prolonged Norovirus Excretion in Highly Immunosuppressed Patients and Children. J. Clin. Microbiol. 2009, 47, 2855-2862. [CrossRef]

25. Ludwig, A.; Adams, O.; Laws, H.J.; Schroten, H.; Tenenbaum, T. Quantitative Detection of Norovirus Excretion in Pediatric Patients with Cancer and Prolonged Gastroenteritis and Shedding of Norovirus. J. Med. Virol. 2008, 80, 1461-1467. [CrossRef]

26. Schorn, R.; Höhne, M.; Meerbach, A.; Bossart, W.; Wüthrich, R.P.; Schreier, E.; Müller, N.J.; Fehr, T. Chronic Norovirus Infection after Kidney Transplantation: Molecular Evidence for Immune-Driven Viral Evolution. Clin. Infect. Dis. 2010, 51, 307-314. [CrossRef]

27. Umeda, Y.; Sakamoto, A.; Nakamura, J.; Ishitsuka, H.; Yagi, Y. Thymosin Alpha 1 Restores NK-Cell Activity and Prevents Tumor Progression in Mice Immunosuppressed by Cytostatics or X-Rays. Cancer Immunol. Immunother. 1983, 15, 78-83. [CrossRef]

28. Rasi, G.; Silecchia, G.; Sinibaldi-Vallebona, P.; Spaziani, E.; Pierimarchi, P.; Sivilia, M.; Tremiterra, S.; Garaci, E. Anti-Tumor Effect of Combined Treatment with Thymosin Alpha 1 and Interleukin-2 after 5-Fluorouracil in Liver Metastases from Colorectal Cancer in Rats. Int. J. Cancer 1994, 57, 701-705. [CrossRef]

29. Rafique, M.; Adachi, W. Effects of Intraportal Administration of Chemoimmunotherapeutic Agents on Natural Killer Cell Activity in the Rat Liver. J. Surg. Oncol. 1995, 60, 154-159. [CrossRef]

30. Hayashi, K.; Nakano, T.; Hashimoto, M.; Kanekiyo, K.; Hayashi, T. Defensive Effects of a Fucoidan from Brown Alga Undaria pinnatifida against Herpes Simplex Virus Infection. Int. Immunopharmacol. 2008, 8, 109-116. [CrossRef]

31. Satoh, A.; Kato, M.; Yamato, K.; Ishibashi, M.; Sekiguchi, H.; Kurano, N.; Miyachi, S. Characterization of the Lipid Accumulation in a New Microalgal Species, Pseudochoricystis ellipsoidea (Trebouxiophyceae). J. Jpn. Inst. Energy 2010, 89, 909-913. [CrossRef]

32. Takahashi, E.; Konishi, S.; Ogata, M. Studies on Cytopathogenic Viruses from Cats with Respiratory Infections. Jpn. J. Vet. Sci. 1971, 33, 81-87. [CrossRef]

33. Kitajima, M.; Oka, T.; Tohya, Y.; Katayama, H.; Takeda, N.; Katayama, K. Development of a Broadly Reactive Nested Reverse Transcription-PCR Assay to Detect Murine Norovirus, and Investigation of the Prevalence of Murine Noroviruses in Laboratory Mice in Japan. Microbiol. Immunol. 2009, 53, 531-534. [CrossRef] [PubMed]

34. Kitagawa, Y.; Tohya, Y.; Ike, F.; Kajita, A.; Park, S.J.; Ishii, Y.; Kyuwa, S.; Yoshikawa, Y. Indirect ELISA and Indirect Immunofluorescent Antibody Assay for Detecting the Antibody against Murine Norovirus S7 in Mice. Exp. Anim. 2010, 59, 47-55. [CrossRef]

35. Haga, K.; Fujimoto, A.; Takai-Todaka, R.; Miki, M.; Murakami, K.; Yokoyama, M.; Murata, K.; Nakanishi, A.; Katayama, K. Functional Receptor Molecules CD300lf and CD300ld within the CD300 Family Enable Murine Norovirus to Infect Cells. Proc. Natl. Acad. Sci. USA 2016, 113, E6248-E6255. [CrossRef] [PubMed]

36. Kitajima, M.; Tohya, Y.; Matsubara, K.; Haramoto, E.; Utagawa, E.; Katayama, H. Chlorine Inactivation of Human Norovirus, Murine Norovirus and Poliovirus in Drinking Water. Lett. Appl. Microbiol. 2010, 51, 119-121. [CrossRef]

37. Ito, T.; Hayashi, K.; Nishiguchi, M.; Hayashi, T.; Iimuna, M. Resveratrol Oligomer C-Glucosides and Antiviral Resveratrol Tetramers Isolated from the Stem Bark of Shorea uliginosa. Phytochem. Lett. 2018, 28, 1-7. [CrossRef] 